\title{
Four decades as an academic librarian
}

\author{
By Edward G. Holley \\ Chapel Hill, North Carolina
}

\section{Remarks at the presentation of the Academic/Research Librarian of the Year Award, ALA Annual Conference in New Orleans, July 11, 1988.}

\begin{abstract}
$\mathbf{F}_{\text {i }}$ irst of all, let me thank the ACRL Awards Committee for selecting me as the 1988 recipient of the Academic/Research Librarian of the Year Award. My special thanks to the chair, Donna Goehner, to ACRL President Joanne Euster, and to the Baker and Taylor Company, which makes the award possible. Their expressions of approval at my selection would gladden the heart of any awardee. I also thank my family, represented here today by my wife, Bobbie Lee, and my daughter Beth, as well as many friends and colleagues whose encouragement and support have played such an important part in my career. No one could have enjoyed more dedicated and generous co-workers than I have experienced.

What does a recipient say in response to such accolades as Gary Kaenzig, of Baker and Taylor, has just read?

Words of appreciation, certainly, which are surely in my case more than perfunctory.

But also, perhaps, some words of reminiscence and gratitude for the privilege of being an academic/research librarian in the post-World War II period, an era which George Bobinski has called "a golden age of librarianship," an assessment with which I very much agree. In 1949 I entered the profession and became a member of ACRL. That is a decision I have never regretted. The four decades since have been a period of tremendous accomplishment for academic/research librarians. They have participated in several revolutions of which
\end{abstract}

the technological revolution has been only the most recent. Consider only a few of the changes in academic libraries in the postwar period: extraordinary expansion of buildings, collections, services, and personnel; increases in student enrollment and faculty size; organizational and technological breakthroughs of almost unimaginable proportions. Through all the peaks and valleys, the downturns and the upswings, there has been steady progress in providing Libraries for Teaching, Libraries for Research, as the title of ACRL's contribution to the ALA Centennial proclaimed. The zest and enthusiasm for our profession, yes, even the battles to make the academic/research library a more important part in the higher education enterprise, have played an important part in that progress. To have contributed to expanding the horizons of our profession and to promoting the profession's goals has been both privilege, and for the most part, pleasure; certainly more pleasure than pain, more joy than sorrow.

Always in those four decades there were the people-librarians and support staff, teaching faculty and administrators, donors and politicians. Together, we were partners in a common cause: the transmission of our heritage, the advancement of knowledge, and the provision of information and recreational resources which a democratic society must have for its survival. We may not have used such current words as "mission," "goals," "objectives," but we had the same principles as we car- 
ried out our respective tasks. In observing the diligence with which colleagues carried out their tasks, I have never ceased to be impressed with the capable, committed, and competent librarians with whom it was my privilege to serve. They have been far more numerous than those who have disappointed me.

We probably do too much wringing of hands about the problems of the present-day academic/ research libraries. Our predecessors had problems as difficult, and we can certainly take courage from the manner in which they solved them. In an ever-changing postwar world, academic/research librarians developed ways of dealing with their problems, both creatively and impressively.

As a library historian, I think it is appropriate to conclude these remarks with a quotation from Justin Winsor, one of the major academic/research library leaders of the 19th century. Writing on college libraries in 1879, Winsor noted: "A collection of good books, with a soul to it in the shape of a good librarian, becomes a vitalized power, among the impulses by which the world goes on to improvement."-Library Journal, 3 (1879): 15.

My hope for the bright young people now joining our ranks is that they may find Winsor's principle as valid for themselves as it has been for me and many other ACRL librarians. And they may also discover that the academic/research library, with a soul to it in the shape of a good librarian, continues to be a vitalized power by which the world goes on to improvement.

\section{The Association of College}

\section{and Research Libraries}

\section{awards program, 1989}

\section{ACRL opportunities and honors for you and your colleagues.}

\footnotetext{
$\mathbf{T}$ he Association of College and Research Libraries sponsors a number of award programs on behalf of academic or research librarianship to recognize special achievements and outstanding publications and to foster professional growth. Someone you know is deserving of special recognition for their contributions to academic and research librarianship. Take a moment to nominate these outstanding individuals so that they can get the recognition they deserve.

Award-winning opportunities for members of ACRL are described on the following pages. Please review the requirements for each award program
}

and take note of the programs for which you or a colleague are eligible.

General submission procedures. Unless otherwise indicated send nominations and applications to: Name of the Award, Association of College and Research Libraries/ALA, 50 East Huron Street, Chicago, IL 60611-2795.

Staff contact. If you have questions or need help in compiling information for a nomination, contact Mary Ellen K. Davis, (800) 545-2433; (800) 545-2444 in Illinois; (800) 545-2455 in Canada; or (312) 944-6780. 